168 Наукові записки ХНПУ ім. Г.С. Сковороди. Літературознавство, 2019, вип. 4(94)

УДК 821.161.2-95-92.09:356.113(477)»191»(092)

І.В. Роздольська

\title{
ЛІТЕРАТУРНИЙ ФЕНОМЕН УКРАЇНСЬКИХ СІЧОВИХ СТРІЛЬЦІВ В ОБ'ЄКТИВІ ЛІТЕРАТУРОЗНАВСТВА: ВІЗІЯ СТРІЛЕЦЬКОЇ СТРУКТУРИ
}

Літературний феномен Українських Січових Стрільців уже давно вийшов за рамки своєї антологійної першопрезентації, здійсненої зусиллями Тараса Салиги книгою «Стрілецька Голгофа». Від часів незалежності України літературознавча бібліографія стрілецтва суттєво зросла, маркером чого $є$ бібліографічний покажчик, присвячений групі «Митуса». Змістове наповнення означених праць спонукає до думки про те, що літературне функціонування українського січового стрілецтва виходить за рамки творчості, літературного роду чи жанру, а змагає до певної структурованості власного прояву, одним із яких є «Митуса» як група і видання.

Звідси викристалізовується потреба узагальнення того досвіду літературознавства зі спостереженнями, ідеями, інспіруючими натяками щодо літературної організованості стрілецького війська і їі прояву у суспільному i літературному житті, що сприятиме окресленню засадничого підходу задля об'єктивного пізнання неординарного явища. Це і становить мету нашої студії.

Періоду визвольного змагу стосується початковий етап уваги до явища стрілецького письменства, позначений значною мірою бажанням літературного самоозначення вояцтва. Спроби стрілецької преси, рукописні «одноднівки» та періодика представили громадськості письменство, марковане «У.С.С.», «стрілець УСС». Чи не найпершим прозвучало імення Романа Купчинського, автора «Новініади», назви стрілецької гумористики, автори якої деперсоналізовано представляли власні твори, позначені псевдонімами, чи то у «Самохотнику», чи то у «Бомбі» витвором єдиного стрілецького творчого духа, що одразу формує фокус 
майбутніх рецепцій - щодо цілості, спільності, спільноти, детермінованої військом, війною, історичною місією.

У період міжвоєння в антології Богдана Лепкого «Струни» (1922) [34] авторів стрілецької когорти залучено до літературної панорами, при цьому надзвичайно виразно підкреслюється зануреність стрілецьких поетів в історичний час, вони «творять окремий поетичний гурт молодих співаків-ентузіастів, які для боротьби за Україну посвятили свої найкращі молодечі літа і поза цією великою ідеєю не бачили нічого більше» [34, с. 268]. Сильвети Р. Купчинського, В. Бобинського, О. Бабія, Л. Лепкого є репрезентантами цього гурту, на думку укладача, при цьому у портреті М. Голубця підкреслено його воєнний чин у Січових стрільцях [34, с. 292]. С часткова увага до функціонального навантаження представників стрілецького покоління у їхній спільноті - так, Л. Лепкий означений як організатор Січових Стрільців разом із «К. Гутковським, Ф. Левицьким та другими» [34, с. 293]. Р. Купчинський - чільний стрілецький поетпісняр [34, с. 268]. Цікаво, що В. Бобинський у антології здійснює автопрезентацію у форматі «автобіографічої замітки», із переліком біографічних фактів щодо власної участі в УСС та УГА з 1916 до квітня 1920 року, в українсько-польській війні [34, с. 283], у якій автору важливішим є його міжвоєнний життєвий етап, на якому «приступив до зложення гурту поетів-приклонників нових шляхів у мистецтві та вів редакцію їхнього журналу «Митуса» [34, с. 283]. Таким чином матеріал антології спонукає до думки про генераційне значення кожного із авторів стрілецької Голгофи

Літературознавча рецепція стрілецької творчості у міжвоєнні оберталася насамперед навколо гурту «Митуса» (1921-1922), який актуалізував у літературній панорамі Галичини імена В. Бобинського, О. Бабія, Р. Купчинського. Ю. Шкрумеляка та підкреслив важливість питання літературно-ідеологічної диференціації у періоді міжвоєння. Портрет групи поставав на перехресті цих рецепцій та самоозначень. Стаття В. Бобинського, «Літературне життя по цей бік Збруча» (1923) [2, с. 449-450] написана 1923 р. для «Нової культури», літературно-мистецька критика часопису «Митуса» (1922), відгуки 
про групу виявляють непростий процес внутрішньої ідеологічноестетичної орієнтації його учасників.

Резонанс «Митуси» став поштовхом для більшої уваги до іiі представників у різноманітних літературних оглядах та працях монографічного типу, у яких часто необхідно враховувати ті особливості інтерпретації, що зумовлені ідеологічними поглядами автора. Так, зокрема в «Антології сучасної української поезії: Поети 20-х років» (Львів, 1936) iї упорядник Свген Юлій Пеленський у передмові «Українські поети 20-их років» [17, с. 5-15] позитивно відзначає зв'язок творчої діяльності О. Бабія, Р. Купчнського із «патосом національних почувань» [17, с. 14], «національною тематикою» [17, с. 9]. Причому «чоловим представником» такої групи поетів, що одночасно із символістською лірикою розвивають тему Визвольних Змагань, представлено Романа Купчинського [17, c. 9].

У «Нарисі сучасної галицької поезії» Меріяма [15] помітне враження від ідейно-естетичного вектора групи, який постає неодноцільним - 3 точки зору ідеолога групи В. Бобинського як орієнтованого на здобутки української радянської символістської поезії, а $з$ точи кору Р. Купчинського - виразно по стрілецьки національним i головним, «початковим i кінцевим акордом: Купчинський жиє в романтиці війни, в стрілецьких окопах і він [...] дає кусники стрілецької душі, живцем вирвані» [15, с. 75]. Стан пам'ятання про стрілецькі часи вирізняє з потоку такий твір, на думу Меріяма, як «Поїзд мерців» Ю. Шкрумеляка, що виринув поза «Митусою». У рядах літературного стрілецтва цього часу помічає $\mathrm{i}$ відзначає також М. Миколу-Мельника. В. Софроніва-Левицького, Е. Яворівського.

У статті Ігоря Коломийціва «Лірики останнього десятиліттям» (1929) значення «Митуси» потрактовано спрощено - на рівні відповідності бажаному радянофільському вектору [9].

У підсумку група «Митуса» як літературна спільнота у міжвоєнні не мала належного осмислення - з точки зору організації, ідеологічно- 
естетичних настанов, співвідношення сил та зв'язку із традицією стрілецької духовної діяльності.

Тема «Митуси» звучатиме у публікаціях української діаспори під кутом відповідності літературно-ідеологічному напрямку міжвоєння. Такою є розвідка Богдана Романенчука «Західноукраїнська література між двома світовими війнами: 1919-1941 роки», у якій творчу практику групи потрактовано в рамках естетсько-модерністського ключа, із негативним ставленням до «зачарованих на схід» із іiі кола [19].

Уже за незалежності в українському літературознавстві з'явилось перше бібліографічне джерело, дотичне до стрілецької теми в літературі, здійснене на матеріалі групи «Митуса»-це бібліогафічний покажчик групи, який підготувала Ліля Сирота 2004 р. Дослідниця під час представлення історико-літературного портрета групи «Митуса» не може оминути так званого іï «організаційного етапу» в історії іi становлення, який означує двома факторами - часом визвольних змагань і участю у мистецькому житті Києва [30, с. 4], розуміючи, що хронологія стрілецького літературного матеріалу не вкладається у рамки групи, існує поза їі контекстом. Складно погодитися iз твердженням про час визвольних змагань як підготовчий етап «Митуси», яка потрактована вершинним організаційним утворенням січового стрілецтва, тим більше, що ціннісні ідеї стрілецтва у час визвольних змагань суттєво різняться від ідей, артикульованих «Митусою». Однак тоді у дослідництві на існуючому історико-літературному матеріалі не могло сформулюватись інших висновків. Також дослідниця зачіпає тему групи «Богема», видань «Маски», «Будяк», «Зиз», до яких січове стрілецтво дотичне [31]. Таким чином опосередковано виринає думка, що січове стрілецтво в літературі виходить за рамки формату літературної групи, іє потреба з'ясування обставин їхньої творчості та організованості, системності/несистемності проявів у час визвольних змагань та міжвоєння. Структура бібліографічного покажчика групи «Митуса» також виходить за рамки хронології іii існування, оскільки авторка виокремлює твори «періоду єдності 
групи» [30, с. 19-50], «їхні передруки 1924-2003 рр.» [30, с. 50-68], залучає і творчість митусівців часів визвольної війни - від 1915 року [30, с. 70-86].

Загалом стрілецький літературний феномен від періоду міжвоєння включено до континууму української культури - від давніх часів до нового часу. Свідченням чого $є$ розвідка «Історія української культури» (Львів, 1937) [8]. Виокремлюючи у розвитку письменства як явище із виразними питомими ознаками «Поезію стрілецького життя» Володимир Радзикевич наголошує на «окремому характері» ii, пов’язаному із «Великим ідейним зривом», що спонукав еліту галицького українського юнацтва «вступити у січово-стрілецькі ряди 1914 року» і проживати життя у форматі військовому, «на полях битв», вважаючи ідейний і збройний чин джерелом появи стрілецької творчості [8, с. 449]. Важливим для нас є сприйняття поезії цілісним явищем. Пов’язаним із «збірною психікою українського стрілецтва», виразом якої постала, яка «виявила його почування, його надії, його розчарування та відбила особисті переживання поодиноких стрільців» [8, с. 450]. однак у нарисі здійснено представлення стрілецького письменства не генераційно, як можна було очікувати, а генологічно, із виокремленням провідних жанрів, вирізненням найбільш частотних. При цьому впадає в око націленість стрілецького творчого «я» на такі творчі форми, що виростають із колективної народної традиції, - сатири. Пісенності, тобто тут переважає фіксація на тих жанрах, які демонструють збірність авторських творчих імпульсів. Бачимо, що автор виходить за рамки поезї, якою обмежився початково у темі нарису, залучив до наукової актуалізації і жанри стрілецької літературної епіки міжвоєння, драми, мемуарнобелетристичної літератури, при цьому пропонуючи певну класифікацію авторів у зазначених ділянках, кількісно досить численну, яка виявляє намір ученого врахувати творчу значущість персоналії в контексті збірної стрілецької діяльності. Так, на його думку, серед кращих стрілецьких літераторів, у «стрілецькому Парнасі» перебувають «Ю. Назарак, М. Голубець, Ю. Шкрумеляк, В. Бобинський, А. Лотоцький, А. Баландюк, Л. Луців, М. Угрин- 
Безгрішний» [8, с. 450]. Серед авторів стрілецької пісні найбільш популярними $є$ С. Чарнецький, Левко Лепкий та Юра Шкрумеляк та композитор Михайло Гайворонський $[8$, с. 450], «на перед» серед яких тут «найбільше вибились Р. Купчинський та Лев Лепкий». Така широта охоплення прізвищ, різножанровість літературної продукції зумовлена вагомими результатами стрілецької видавничої діяльності у концерні «Червона Калина», націленого на просування стрілецького тексту.

Маємо спорадичну увагу до літературно-видавничої діяльності стрільців у період визвольної боротьби, здійснюваної у форматі журналу «Шляхи», Стрілецького Калєндаря-Альманаха на 1917 рік та збірника «Червона Калина» 1918 року видання за редакцією М. Угрина-Безгрішного та «великої Антольогії УСС» Л. Геца та В. Бобинського [8, с. 450], таким чином через назви видань звертає на себе увагу структурний аспект періоду.

У період державної незалежності відновилася дослідницька увага до стрілецької теми. У літературознавстві етапним виданням великої інспіруючої сили $\epsilon$ «Стрілецька Голгофа» Тараса Салиги (Львів, 1992) [33], у якій представлено вперше сукупно під знаком зв'язку із стрілецьким визвольним рухом низку імен. Структурою своєю орієнтована тему стрілецького чину представити в певній хронологічній тяглості - «спочатку подаємо просвітницьку поезію, присвячену масово-культурним осередкам, та національнопросвітницькі твори авторів-класиків. Потім ідуть вірші групи, сказати б, «негуманітарних» поетів, відтак військових провідників Українських січових стрільців, твори «молодомузівців», вірші безпосередніх учасників війни i нарешті представників постстрілецтва - поетів молодшого покоління» [33, с. 5]. Відразу виникає питання зв'язку між авторами стрілецької генерації та «іншими», чим для них була стрілецька визвольна ідея та стрілецька тема, і як означувати тих «інших» відносно стрілецтва, найстаріших, трохи старших, ровесників, чи існує певний спільний знаменник узгодження і тлумачення? Розуміємо, що не завжди поясненням може бути тематичний підхід, і що він потребує корекції в діахронії 
174 Наукові записки ХНПУ ім. Г.С. Сковороди. Літературознавство, 2019, вип. 4(94)

i на синхронному рівні встановленням взаємозв'язків між стрілецтвом та іншими історико-літературними явищами. Переклад i введення у літературознавчий дискурс у 2009 році статті Б.І. Антонича («Поезія по цей бік барикади» [1]), написаної 1934 р., у якій ідеться про синхронне існування у потоці літературного життя двох воєнних груп, не тотожних собі, одна із яких стрілецька, а інша - із учасників армії УНР, лише підсилили актуалізацію структурного принципу осмислення стрілецького літературного феномену.

Введення теми «Стрілецької поезії» до академічного видання «Історії української літератури ХX ст.» 1993 року [7] також стимулювало подальшу дослідницьку увагу до неї.

У дослідницькому набутку Т. Салиги із 1989 року постала низка перших літературних стрілецьких сильвет в українській періодиці О. Бабія [25], Р. Купчинського [20, 22, 27, 29], Л. Лепкого [26], М. Голубця [21] із віршовим супроводом, які сукупно апробують тему «Стрілецької Голгофи» у науці. У наступних літературознавчих студіях за персоналіями стрілецького змагу «стрілецький» маркер ідентифікує літературні сильвети - О. Бабія [35], М. МатіїваМельника [12], Р. Купчинського [14], Ю. Шкрумеляка [36], які постали в літературознавстві за незалежності, найбільшою генераційною прикметою цих праць є осмислення творчої постаті у зв'язку із історичним часом, її середовищем, духом епохи.

Поколіннєві зв'язки стрілецтва опосередковано увиразнено у публікаціях, присвячених реалізації січовим стрілецтвом практики символізму. Тут на перший план виходить естетичний зв'язок із мистецькими пошуками групи «Молода Муза» у працях Т. Салиги «Літературна група «Митуса» і друга хвиля українського символізму» [23], «Літературна група «Митуса» і іiі стильові пошуки» [24], «Українська поезія періоду міжвоєння: Шляхи і напрями» [28], М. Ільницького «На перехрестях віку» [5, с. 10-12], «Драма без катарсису: Сторінки літературного життя Львова першої половини ХX ст.» [4, с.10-30], «Від «Молодої музи» до «Празької школи»» [6, c. 258-562]. 
У дослідженнях, присвячених функціонуванню літературного процесу міжвоєння - Романа Олійника-Рахманного [16], Мар'яни Комариці [10], Наталії Мафтин [13], М. Дубини [2] уміщено чимало цінних штрихів до літературного силуету стрілецької генерації, актуалізуючись у проблемі ії дотичності до окреслених літературноідеологічних напрямків - насамперед «націоналістичного» i «прорадянського». Оригінально прочитує окремі твори стрілецького міжвоєнного дискурсу Н. Мафтин - 3 точки зору концепту реконкісти. Із появою бібліографічного покажчика Валентини Перидирій «Видання «Червоної Калини» 1922-1939» [18, с. 5-6] постало питання відтворення літературного силуету січового стрілецтва у структурі літературно-видавничого концерну «Червона Калина»

Чимало розвідок, дотичних до діяльності січового стрілецтва, розглядають їхній духовний продукт у пресознавчому аспекті. Серед наукових здобутків українського пресознавства варто відзначити ті роботи, у яких зачіпаються окремі питання функціонування стрілецьких літературних сил у галицьких виданнях перших десятиліть XX століття і міжвоєнного двадцятиліття. Так, праці Аркадія Животка [3] та Івана Крупського [11] увиразнюють дотичність січового стрілецтва до видань визвольної війни, актуалізуючи окремі друковані органи, у яких воно було задіяне. Лідія Сніцарчук увиразнила власною монографією «Українська сатирично-гумористична преса Галичини 20-30-х рр. ХХ ст.» (Львів, 2001) [32] не лише жанрово-тематичні обрії видань міжвоєнного періоду, до створення і функціонування яких були залучені стрілецькі сили, а й по можливості встановила значущість цих аналізованих видань, ступінь популярності, а отже i впливу на читацьке середовище. У монографії - першоінтерпретація міжвоєнної преси під кутом співвідношення проблематики гумору i сатири із актуальним соціально-історичним часом, авторка враховує стрілецький сегмент, залучаючи факти діяльності січових стільців у виданнях, розкриваючи псевдоніми, однак представлення окремих видань сатиричної преси як продукту стрілецького мислення зі специфічним образом світу, тут немає, присутні натомість спорадичні 
спостереження щодо окремих, співзвучних стрілецтву тем. Розвідка $\epsilon$ цінною щодо функціонування у польському політично-державному хронотопі видань «Будяк», «Маски». «Зиз», у яких стрілецькі сили були задіяні, де застосовували траєкторії редакційної роботи із часів «Пресової кватири». Зауваження щодо стрілецького походження зазначених видань через стрілецьке минуле засновників і працівників продуктивно спонукає нас до думки сприймати i науково осмислювати - в єдності пресового стрілецького дискурсу, зв'язаного генетичним контекстом часів визвольної війни, тодішніх структурнолітературних установок січового стрілецтва - як літературно-пресові спільноти стрілецького характеру.

Отже у студіях, присвячених творчому феномену українського січового стрілецтва можна спостерегти посилення динаміки в увазі до стрілецької персоналії, стрілецьких спільнот, груп і видань, що реалізується у доповненні фактажу щодо функціонування істориколітературного явища на різних власних етапах. Водночас вони демонструють явну неповноту у проблемі генераційного представлення стрілецької когорти у літературному процесі, як i велику інспіраційну силу. Праці націлюють формувати хронологічні рамки дослідницького фокусу в межах років Визвольної війни та міжвоєнного часу, коли стрілецька спільнота проявлялась системно і цілісно, є потреба реконструкції літературно маркованих структур обох періодів, встановлення генераційного значення групи «Митуса», характеристики стрілецтва у межах міжвоєнних ідейно-естетичних домінант, актуальною постає проблема реконструкції персоналійних рядів у межах літературно-маркованих спільнот, а також значущості стрілецької персоналії у них, а також генераційної комунікації стрілецтва зі старшими та сучасниками і ставлення до них.

\section{Література}

1. Антонич Б.І. Поезія по цей бік барикади. Повне зібрання творів. Львів: Літопис, 2009. С. 898-905.

2. Бобинський В. Гість із ночі: Поезія. Проза. Публіцистика. Літературна критика. [Переклади /упоряд.; передм.; приміт. М.І. Дубини]. Київ: Дніпро, 1990. 623 с. 
3. Животко А. Історія української преси. Мюнхен: Український ТехнічноГосподарський Інститут, 1989-1990. 334 с.

4. Ільницький М. Драма без катарсису: Сторінки літературного життя Львова першої половини ХХ ст. Львів: Місіонер, 1999. 210 с.

5. Ільницький М. На перехрестях віку. Над рікою часу: Західноукраїнська поезія 20-30-х років. Харків: Фоліо, 1999. С. 5-23.

6. Ільницький М. На перехрестях віку: У трьох книгах. Київ: Вид. дім «Києво-Могилянська академія», 2009. Кн. III. 902 с.

7. Ільницький М. Стрілецька поезія. Історія української літератури XX століття. У 2 кн. Кн. 1.: 1910-1930-ті роки: Навч. посібн [За ред. В.Г. Дончика]. Київ: Либідь, 1993. С. 277-279.

8. І Історія української культури. Львів: вид. Івана Тиктора, 1937. 718 с.

9. Коломийців I. Лірики останнього десятиліття (1919-1929): IV, V, VI. Нові шляхи. Львів, 1929. Ч. 4 (серпень). С. 322-333.

10. Комариця М. Українська «католицька критика»: феномен 20-30-х рр. ХХ ст. Львів, 2007. 328 с.

11. Крупський I.В. Національно-патріотична журналістика України (II половина XI - I чверть XX ст.). Львів: Світ, 1995. 184 с.

12. Курищук В. «Аж доки думки ніч не стане...» (Із життя і творчості Миколи Матіїва-Мельника). Українське літературознавство. Львів, 1994. Вип. 59. С. 53-64.

13. Мафтин Н.В. Західноукраїнська та еміграційна проза 20-30-х років XX століття: парадигма реконкісти: монографія. Івано-Франківськ: ВДВ ЦТТ Прикарпатського національного університету імені Василя Стефаника, 2008. 356 с.

14. Мельник М.В. Літературний портрет Романа Купчинського: жанрові та художньо-стильові аспекти: автореф. дис. ... канд. філол. наук: спец. 10.01 .01 «Українська література». Львів, 2008. 19 с.

15. Меріям. Нарис сучасної галицької поезії. Літературно-Науковий Вістник. Львів, 1925. Т. LXXXVIII. Кн. IX. С. 70-79.

16. Олійник-Рахманний Р. Літературно-ідеологічні напрямки в Західній Україні (1919-1939 роки). Роман Олійник-Рахманний. Київ: Четверта хвиля, 1990. $240 \mathrm{c.}$

17. Пеленський Є.Ю. Українські поети 20-их років. Євген Юлій Пеленський. Антологія сучасної української поезії: Поети 20 -х років. Львів: Накладом «Рідної школи» і «Ізмарагду», 1936. С. 5-15. 
18. Передирій В. Видання «Червоної Калини» 1922-1939: Історикобібліографічне дослідження. Львів, 2004. 357 с.

19. Романенчук Б. Західноукраїнська література між двома світовими війнами 1919-1941 роки. Записки НТШ. Т. ССХІІ. Філологічна секція. Львів - Нью Йорк - Париж - Сідней - Торонто, 1996. С. 232-255.

20. Салига Т. Вилітали орли.... [Р. Купчинський]. Просвіта. 1989. Листоп. C. 4.

21. Салига Т. 3 вирію літ: Про літературний доробок М. Голубця. Просвіта. 1990. Вип.9. С. 4.

22. Салига Т. Курилася доріженька: Про Романа Купчинського та українську стрілецьку поезію. Україна. 1990. №6. С. 6-8.

23. Салига Т. Літературна група «Митуса» i друга хвиля українського символізму. Другий Міжнародний конгрес україністів. Львів, 1993. C. $168-173$.

24. Салига Т. Літературна група «Митуса» і їі стильові пошуки. Салига T. Імператив (Літературознавчі статті, критика, публіцистика). Львів: Світ, 1997. С. 99-108.

25. Салига Т. Любов і ненависть: [ О. Бабій]. Просвіта. 1989-1990. Груд.ciч. C. 4.

26. Салига Т. Один з родини: [Про стрілецькі пісні Л. Лепкого]. Просвіта. 1990. Вип. 6. Січ. С. 4.

27. Салига Т. Поет із коша стрілецького (Р. Купчинський). Літературна панорама. К.: Дніпро, 1990. Вип.5. С. 194-204.

28. Салига Т. Українська поезія періоду міжвоєння: Шляхи і напрями. Салига Т. Високе світло: Літ.-критич. студії. Львів: Каменяр; Мюнхен: Укр. Вільний ун-т, 1994. С. 5-46.

29. Салига Т. Чи дійсність це була....: [Р. Купчинський]. Салига Т. Імператив: (Літературознавчі статті, критика, публіцистика). Львів: Світ, 1997. C. 323-329.

30. Сирота Л. Літературна група «Митуса» (1921-1922): О. Бабій, В. Бобинський, Р. Купчинський, Ю. Шкрумеляк: Бібліографічний покажчик. Львів: НДЦ періодики, ЛНБ ім. В.Стефаника, НАН України, 2004. $190 \mathrm{c}$.

31. Сирота Л. Літературна група «Митуса» (до висвітлення життєвого $\mathrm{i}$ творчого шляху іiї представників). Рукописна україніка у фондах Львівської наукової бібліотеки ім. В. Стефаника НАН України та 
проблеми створення інформаційного банку даних. Львів, 1996. С. $263-$ 275.

32. Сніцарчук Л.В. Українська сатирично-гумористична преса Галичини 20-30-х pp. XX ст.: історико-функціональний аспект та інтерпретаційні особливості. Львів, 2001. 240 с.

33. Стрілецька Голгофа: спроба антології. [Упоряд., авт. вступ. ст і прим. Т.Ю. Салига; худ. оформл. І.П. Плесканка]. Львів: Каменяр, 1992. 399 с.

34. Струни: Антологія української поезії від найдавніших до нинішніх часів для вжитку школи й хати влаштував Богдан Лепкий. Ч. II. Берлін: Спільне видання «Українського Слова» i «Української народньої бібліотеки», 1922. $296 \mathrm{c.}$

35. Утріско О. Літературна сильвета Олеся Бабія у журналі «Маски». Українське літературознавство. Львів, 2012. Вип. 75. С.232-238.

36. Хороб М. Юра Шкрумеляк: Один із чети крилатих (сторінки життєвої й творчої біографії на тлі суспільних подій перших десятиліть ХХ ст.). Сівач духовності: Зб. спогадів, статей і матеріалів, присв. проф. В. Полєку. Івано-Франківськ: Плай, 2002. С. 197-210.

\section{References}

1. Antonych, B.I. Poeziia po tsei bik barykady [Poetry on this side of the barricade]. In: Antonych, B.I. Complete works, 898-905. Lviv, 2009.

2. Bobynskyi, V. Hist iz nochi: Poeziia. Proza. Publitsystyka. Literaturna krytyka. Pereklady [Guest in the night: Poetry. Prose. Nonfiction. Literary criticism. Translations]. Kyiv, 1990.

3. Zhyvotko, A. Istoria ukrainskoi presy [History of Ukrainian press]. Miunkhen, 1989-1990.

4. Ilnytskyi, M. Drama bez katarsysu: Storinky literaturnoho zhyttia Lvova pershoi polovyny XX st. [Drama without catharsis: Pages of the literary life of Lviv in the first half of the twentith century]. Lviv, 1999.

5. Ilnytskyi, M. Na perekhrestiakh viku [At the crossroads of the age]. In: Nad rikoiu chasu: Zakhidnoukrainska poeziia 20-30-kh rokiv, 5-23. Kharkiv, 1999.

6. Ilnytskyi, M. Na perekhrestiakh viku: U triokh knyhakh [At the crossroads of the age: in three books]. Kyiv, vol. III (2009).

7. Ilnytskyi, M. Striletska poeziia [Rifle poetry]. Istoriia ukrainskoi literatury XX stolittia. U 2 kn. Kn.1.: 1910-1930-ti roky, 277-279. Kyiv, 1993.

8. Istoriia ukrainskoi kul'tury [History of Ukrainian culture]. Lviv, 1937. 
180 Наукові записки ХНПУ ім. Г.С. Сковороди. Літературознавство, 2019, вип. 4(94)

9. Kolomyitsiv, I. Liryky ostannioho desiatylittia (1919-1929): IV, V, VI [The lirycs of the last decade (1919-1929)]. Novi shliakhy. Lviv, 4 (1929): 322333.

10. Komarytsia, M. Ukrainska «katolytska krytyka»: fenomen 20-30-kh rr. $\mathrm{XX}$ st. [Ukrainian «Catholics criticism»: phenomenon of 20-30-th of XX century]. Lviv, 2007.

11. Krupskyi, I.V. Natsionalno-patriotychna zhurnalistyka Ukrainy (II polovyna XIX - I chvert XX st.) [National-patriotic journalism of Ukraine: II half of XIX - I quarter of XX cent.]. Lviv, 1995.

12. Kuryshchuk, V. «Azh doky dumky nich ne stane...» (Iz zhyttia i tvorchosti Mykoly Matiiva-Mel'nyka) [«Until thoughts night...» (From the life and works of Mykola Matiiv-Melnyk]. Ukrainske literaturoznavstvo mizhvidomchyi naukovyi zbirnyk. Lviv, 59(1994): 53-64.

13. Maftyn, N.V. Zakhidnoukrainska ta emihratsiina proza $20-30$-kh rokiv XX stolittia: paradyhma rekonkisty : monohrafiia [Western Ukrainian and Emigration prose of the 20-30-ts of the twentieth century: the Reconquista paradigm]. Ivano-Frankivsk, 2008.

14. Melnyk, M.V. Literaturnyı̌ portret Romana Kupchyns'koho: zhanrovi ta khudozhn'o-styl'ovi aspekty [Literary portrait of Roman Kupchynski: genre and artistic-stylistic aspects] Extended abstract of $\mathrm{PhD}$ dissertation (Ukrainian literature). Ivan Franko National University. Lviv, 2008.

15. Meriiam. Narys suchasnoi halytskoï poezii [Essay on modern Galician poetry]. Literaturno-Naukovyi Vistnyk. L'viv, vol. LXXXVIII, IX (1925): 70-79.

16. Oliinyk-Rakhmannyi, R. Literaturno-ideolohichni napriamky v Zakhidnii Ukraini (1919-1939 roky) [Literary and ideological trends in Western Ukraine (1919-1939)]. Kyiv: Chetverta khvylia, 1990.

17. Pelenskyi, Ye.Yu. Ukrainski poety 20 -ykh rokiv [Ukrainian poets of 20-th]. Antolohiia suchasnoi ukrainskoï poezii: Poety $20 \mathrm{kh}$ rokiv, 5-15. Lviv, 1936.

18. Peredyrii, V. Vydannia «Chervonoï Kalyny» 1922-1939: Istorykobibliohrafichne doslidzhennia [«Red Kalyna» publishing house 1922-1939: Historacal and bibliographic research]. Lviv, 2004.

19. Romanenchuk, B. Zakhidnoukrainska literatura mizh dvoma svitovymy viinamy 1919-1941 roky [Western Ukrainian Literature between the two world wars 1919-1941]. Zapysky NTSh. Filolohichna sektsiia. CCXII (1996): 232-255. 
20. Salyha, T. Vylitaly orly...: [R. Kupchynskyi] [The eagles flew...: R. Kupchynskyi]. Prosvita 11 (1989): 4.

21. Salyha, T. Z vyriiu lit: Pro literaturnyi dorobok M. Holubtsia [From years to years: About literary achivements of M.Holubets] Prosvita 9 (1990):4.

22. Salyha, T. Kurylasia dorizhen'ka: Pro Romana Kupchynskoho ta ukrainsku strilets'ku poeziiu [Smoking road: About Roman Kupchynskyi and Ukrainian rifle poetry]. Ukraina 6 (1990): 6-8.

23. Salyha, T. Literaturna hrupa «Mytusa» i druha khvylia ukrainskoho symvolizmu [The «Mytusa» literary group and second wave of Ukrainian symbolism]. Druhyi Miznarodnyi konhres ukrainistiv, 168-173. Lviv, 1993.

24. Salyha, T. Literaturna hrupa «Mytusa» i iï stylovi poshuky [The «Mytusa» literary group and its style searches]. Salyha T. Imperatyv (Literaturoznavchi statti, krytyka, publitsystyka), 99-108. Lviv, 1997.

25. Salyha T. Liubov i nenavyst: [O. Babii] [The love and the hate: O. Babii]. Prosvita 12-1 (1989-1990): 4.

26. Salyha, T. Odyn z rodyny: [Pro striletski pisni L. Lepkoho] [One of the family: About L. Lepkyi`s rifle songs]. Prosvita 6 (1990): 4.

27. Salyha, T. Poet iz kosha strilets'koho (R. Kupchynkyi) [Poet from the rifle group (R. Kupchynkyi)]. Literaturna panorama 5(1990): 194-204.

28. 28.Salyha, T. Ukrainska poeziia periodu mizhvoiennia: Shliakhy i napriamy [Ukrainian poetry of the interwar period: ways and directions]. Salyha T. Vysoke svitlo: Lit.-krytych. Studii, 5-46. Lviv: Kameniar; Miunkhen: Ukr. Vi'nyi un-t, 1994.

29. Salyha, T. Chy diisnist tse bula...: [R. Kupchynkyi] [Was it really... R. Kupchynkyi]. Salyha T. Imperatyv: (Literaturoznavchi statti, krytyka, publitsystyka), 323-329. Lviv, 1997.

30. Syrota, L. Literaturna hrupa «Mytusa» (1921-1922): O. Babii, V. Bobynskyi, R. Kupchynskyi, Yu. Shkrumeliak: Bibliohrafichnyı̌ pokazhchyk [The «Mytusa» literary group (1921-1922): O. Babii, V. Bobynskyi, R. Kupchynskyi, Yu. Shkrumeliak: The bibliographic index ]. Lviv, 2004.

31. Syrota, L. Literaturna hrupa «Mytusa» (do vysvitlennia zhyttievoho i tvorchoho shliakhu ii predstavnykiv) [The «Mytusa» literary group (to the coverage of the life and creative way of its representatives)]. Rukopysna ukrainika u fondakh Lvivskoi naukovoi biblioteky im. V. Stefanyka NAN Ukrainy ta problemy stvorennia informatsiĭnoho banku danykh, 263-275. Lviv, 1996. 
32. Snitsarchuk, L.V. Ukrainska satyrychno-humorystychna presa Halychyny 20-30-kh rr. XX st.: istoryko-funktsionalnyi aspekt ta interpretatsiini osoblyvosti [Ukrainian satirical-humorous press of Galicia of the 20-30-ts of the XX century: historical-functional aspect and interpretative features]. Lviv, 2001.

33. Striletska Holhofa: sproba antolohii [Rifle Calvary: an Anthology attempt] Lviv, 1992.

34. Struny: Antologiia ukrainskoï poezii vid naidavnishykh do nynishnikh chasiv dlia vzhytku shkoly i khaty vlashtuvav Bohdan Lepkyi. Ch. II. [Strings: An Anthology of Ukrainian poetry from ancient to present for the use of school and home by Bohdan Lepkyi. Part II]. Berlin, 1922.

35. Utrisko O. Literaturna sylveta Olesia Babiia u zhurnali «Masky» [Oles Babii`s literary silhouette «Masks» magazine]. Ukrainske literaturoznavstvo 75 (2012): 232-238.

36. Khorob M. Yura Shkrumeliak: Odyn iz chety krylatykh (storinky zhyttievoi i tvorchoi biohrafii na tli suspilnykh podii pershykh desiatyli' XX st.) [Yura Shkrumeliak: The one from the winged wing (the pages of life and creativity on the background of the social events of the first decades of the XX-th century]. Sivach dukhovnosti: Zb. spohadiv, statei i materialiv, prysv. prof. V. Polieku, 197-210. Ivano-Frankivsk, 2002.

\begin{abstract}
Анотація
І.В. Роздольська Літературний феномен Українських Січових Стрільців в об'сктиві літературознавства: візія стрілецької структури

У статті автор мав на меті здійснити огляд літературознавчих праць, присвячених літературній діяльності Українських січових Стрільців, у яких актуалізований генераційний аспект її представлення, або ж уміщені думки інспіруючого значення. Таким чином до аналізу було залучено джерела від міжвоєнного часу починаючи і аж до наших днів. Лінійку дослідницьких персоналій від міжвоєнного періоду до повоєнного формують імена галицьких дослідників А. Животка, С. Пеленського, Б. Романенчука, Р. Олійника-Рахманного, І. Коломийціва, Меріяма, В. Радзикевича. За доби незалежності України суттєвий внесок у розробку теми стрілецької літератури вніс Тарас Салига, низка публікацій якого у сукупності спонукає шукати напрямки можливих досліджень. Особливо у його доробку вирізняється антологія «Стрілецька Голгофа», структура якої власне і скеровує нас у бік генераційного погляду на літературу січового стрілецтва,
\end{abstract}


хоч автор наголошував на тематичному принципі упорядкування книги, а не на структурно-соціальному. Продовжувачами у темі стрілецького письменства постають Н. Мафтин, М. Хороб, Л. Сирота, М. Мельник, О. Утріско, фокусуючись на окремих персоналіях зі стрілецької шеренги. При цьому виразною $є$ інтенція усіх дослідників бачити творчу стрілецьку постать в об'єктиві культурно-історичного часу, в потоці подій, що для генераційного підходу $\epsilon$ продуктивним. М. Ільницький актуалізував феномен січових стільців відповідним розділом в академічному підручнику «Історії української літератури». Важливим чинником у сприйнятті стрілецького гурту є чинник літературно-ідеологічного напрямку, що його опосередковано вирізняють праці М. Комариці, Р. Олійника-Рпхманного, I. Коломийціва як домінанту міжвоєнного літературного процесу в Галичині, за якою визначалися усі літературні сили тогочасся. Також на основі представлених праць можна виснувати про необхідність розгляду стрілецького літературного буття в рамках пресових структур, які стрільці творили самі, від початку визвольних змагань і до початку другої світової війни, таким чином відповідно структуруючись у рамках літературного процесу. Розвідки І. Крупського, Р. Олійника-Рахманного, Л. Сніцарчук, В. Перидерій, вказують, що такий розгляд може бути продуктивним. Так само слід враховувати великий емоційний зв'язок стрілецьких авторів із обраним літературно-ідеологічним напрямком, полемічність комунікації особливо у міжвоєнний час.

Ключовіслова: Українськісічові стрільці,генерація, літературознавство, персоналія, «Митуса», група, преса.

\section{Аннотация}

И.В. Роздольськая. Литературный феномен Украинских Сечевых Стрельцов в обьективе литературоведения: видение стрелецкой структуры

В статье автор был нацелен представить обзор литературоведческих трудов, посвященных литературной деятельности Украинских Сечевых Стрельцов, в которых актуализирован генерационный аспект еe презентации, или же присутствуют мысли вдохновляющего значения. Таким образом для анализа были взяты источники от межвоенного времени и до наших дней. Линейку исследовательских имен от периода межвоенного и до современного формируют имена галицких ученых А. Животко, Е. Пеленского, Б. Романенчука, Р. Олиныка-Рахманного, И. Коломыйцива, 
Мрияма, В. Радзикевича. В период независимости Украины существенный вклад в разработку темы стрелецкой литературы внес Тарас Салыга, ряд публикаций которого в совокупности намечает направления возможных исследований. Особенно в его работах выделяется антология «Стрелецкая Голгофа», структура которой собственно и направляет к мысли о генерационном взгляде на литературу сечевого стрелецтва, хотя автор подчеркивал на тематическом принципе составления книги, а не структурносоциальном. Продолжателями темы стрелецкой литературы являются Н. Мафтын, М. Хороб, Л. Сырота, М. Мельник, О. Утриско, фокусируясь на отдельных персоналиях из стрелецкой шеренги. При этом выразительной остается интенция всех исследователей видеть творческую стрелецкую личность в обьективе культурно-исторического времени, в потоке событий, что для генерационного подхода является продуктивным. М. Ильницкий актуализировал феномен сечевых стрельцов отдельным разделом в учебнике «история украинской литературы». Важным фактором в восприятии стрелецкого сообщества есть также фактор литературноидеологического направления, косвенно выделяемый М. Комарыцем, Р. Олийнык-Рахманным, И. Коломыйцивым доминантой межвоенного литературного процесса в Галиции, по которой определялись все литературные силы тех времен. Также на основе представленных исследований можно сделать выводы о необходимости рассмотрения стрелецкой литературной жизни в рамках структур прессы, создаваемых стрельцами, от начала освободительного движения и до начала второй мировой войны, таким образом структурируясь в рамках литературного процесса. Работы И. Крупского, Р. Олийныка-Рахманного, Л. Сницарчук, В. Перидерий являются примером того, что такой подход может быть продуктивным. Также необходимо учитывать большую эмоциональную связь стрелецких авторов с выбранным литературно-идеологическим направлением, полемичность коммуникации, особенно в межвоенном периоде.

Ключевые слова: Украинские Сечевые Стрельцы, генерация, литературоведение, персоналия, «Мытуса», группа, пресса. 


\section{Summary}

\section{I.V. Rozdolska. The literary phenomenon of Ukrainian Sich Riflemen in the lens of literary studies: the vision of the riflemen structure}

In the article the author aimed to review the literary studies devoted to the literary activity of Ukrainian Sich Riflemen, which updated the generational aspect of its presentation, or placed thoughts of inspiring significance. Thus, sources from the interwar period, starting up to the present day, were included in the analysis. The names of Galician researchers A. Zhivotko, E. Pelenskyi, B. Romanenchuk, R. Oliynyk-Rakhmannyi, I. Kolomyitsiv, Miriyam, V. Radzikevich form the line of research personalities from the interwar period to the postwar period. In the days of Ukraine's independence, Taras Salyha made a significant contribution to the development of the topic of rifle literature, a series of publications which together outlines directions for possible research. The «Riflemen Calvary» anthology is particularly distinguished in his work, the structure of which actually directs us towards the generational view of the literature of Sich Riflemen, although the author emphasized on the thematic principle of ordering the book, not structural and social. N. Maftyn, M. Khorob, L. Syrota, M. Melnyk and O. Utrisko succed in riflemen writing theme, focusing on individual persons from riflemen file. M. Ilnytsky actualized the phenomenon of Sich riflemen by a corresponding section in the academic textbook «History of Ukrainian Literature». An important factor in the perception of the shooting group is the factor of the literary-ideological direction, which is indirectly distinguished by the works of M. Komaritsa, R. Oliynyk-Rahmannyi, I. Kolomyitsiv as the dominant of the interwar literary process in Galicia, by which all literary forces were determined. Also, based on the presented works, it is possible to conclude the need to consider the riflemen literary existence within the press structures that the shooters made themselves, from the beginning of the liberation competitions until the beginning of the Second World War, thus structuring accordingly in the framework of the literary process. Reconnaissance of I. Krupskyi, R. Oliynyk-Rakhmannyi, L. Snitsarchuk, V. Peryderiy indicate that such consideration can be productive. It is also necessary to take into account the great emotional connection of the rifle authors with the chosen literary and ideological direction, the polemics of communication especially in the interwar period.

Keywords: Ukrainian Sich Riflemen, generation, literary criticism, personalities, «Mytusa», group, press. 
186 Наукові записки ХНПУ ім. Г.С. Сковороди. Літературознавство, 2019, вип. 4(94)

\section{Інформація про автора}

Роздольська Ірина Володимирівна - кандидат філологічних наук, доцент, доцент кафедри української літератури імені акад. М. Возняка Львівського національного університету імені Івана Франка, вул. Університетська, 1, м. Львів, 79000, Україна; e-mail: yaremchuk.iryna74@ gmail.com; https://orcid.org/0000-0002-3308-1981. 